\title{
Implementation of Recommendation Model for Determining the Marketing Area Location of Creative Industry Products
}

\author{
Rahma Wahdiniwaty \\ Master of Management Program \\ Universitas Komputer Indonesia \\ Bandung, Indonesia \\ rahma@unikom.ac.id
}

\author{
Eko Budi Setiawan \\ Informatics Engineering \\ Universitas Komputer Indonesia \\ Bandung, Indonesia \\ eko@email.unikom.ac.id
}

\author{
Deden A Wahab \\ Master of Management Program \\ Universitas Komputer Indonesia \\ Bandung, Indonesia \\ dedenwahabs@unikom.ac.id
}

\begin{abstract}
Marketing of products from the creative industry needs to be done by the business actors by looking at several aspects, including the selection of locations or places to market their products. This research was conducted to provide a model that can be used by business actors in determining the most appropriate location to market their products. The model has been implemented using Analytical Hierarchy Process method and has been tested to several business actors. Tools used to perform the analysis process Expert Choice. The recommended location weight difference occurs because each business actor, and the type of industry have different perceptions in the interest rating. The result obtained in this research is a model created can be used to assist business actors in determining which location is most appropriate to market products of creative industries.
\end{abstract}

Keywords - recommendations, marketing, products, creative industries, analytical hierarchy process

\section{INTRODUCTION}

Currently many business actors, especially creative industries that are growing or even just starting a business. The existence of creative industries, especially the scale of MSMEs in Indonesia can increase state revenues, so the government is very supportive of the development of the creative industry.

Many factors can affect the creative industry business continuity. These factors can be external or internal factors [1]. In addition, it should also be seen from the side of consumers who actually look more than the price factor [2].

Determining the location of sales can increase consumer interest to buy, any change of location will decrease consumer purchase intention. A good location factor is relative to each different type of business [3-4].

There are three kinds of creative industries whose existence has the highest percentage creative industries are culinary, fashion and craft. The three types of creative industries certainly have different characteristics, ranging from target consumers, business strategy, marketing to the location where the sale[5].

The use of information technology in various forms is also widely used as a media campaign, such as geographic information systems based on the website, based on android mobile and the use of E-Commerce [6-8]. Different strategies will work well if both parties working together both creative industry actors and promotional facility provider partners collaborate and communicate well [9].

This research focuses on selecting sales locations because the location has a significant effect on consumer repurchase as well as consumer satisfaction [10-11]. For that determination of the exact location of sales will help the sellers who in this case is the business of creative industries to market their products to the maximum so as to obtain high profits. To determine the exact location of the sale, some assessment or criteria from that location are required. The process of selectings the appropriate location based on several criteria, can use Analytical Hierarcy Process (AHP) method.

The AHP method is widely used to assist in various election processes, including the selection of air ticket booking applications as well as the selection of store locations, the selection of brake friction and supplier selection [12-15].

AHP is developed and which is used for multicriteria decision making. The basic principle of the AHP method is to create a hierarchy, criteria and alternative judgments, determine priorities and pay attention to consistency [16-17].

In the case of creative industry, the creative economy is defined as any economic activity that creates creativity (intellectual property), culture and cultural and environmental heritage as the foundation of the future. Meanwhile, the creative industry is based on creativity, skills, and talents that have the potential to improve welfare and job creation by creating and exploiting Intellectual Property Rights (IPR).

Creative economy has 14 industry subsectors, namely advertising, architecture, art and antiques market, craft, design, fashion, video/film/animation/photography, games, music, performing arts (showbiz), publishing/printing, software, television/ audio (broadcasting), and research \& development $(\mathrm{R} \& \mathrm{D})$. If speaking without looking at the industry: like advertising, architecture. Can be said as a creative economy (see in totality). Whereas if it specifically talks about its industry groups such as advertising, architecture, it is often said to be an industry group.

Marketing area location is the location of the store in a strategic area so as to maximize profit [18]. Marketing location can also be interpreted as a place to serve consumers and to display merchandise. The main factors that can be considered in the process of location selection are the 
availability of raw materials, the location of the intended market, the availability of energy sources, water and communication facilities, the availability of labor, the availability of means of transportation [19-20].

There are three important things that must be decided to choose a trading location, namely area consideration, consideration of market area, as well as consideration of site characteristics [21-23]. The analytical hierarchy process method in some of that research has not been implemented to provide recommendations for determining marketing locations.

\section{Area Considerations}

Considerations used to decide the location of the territory are:
a. Population conditions
b. City network
c. Environmental characteristics
d. Economic characteristics
e. Target market
f. Local culture
g. Competition
h. Level of shopping mall saturation
i. Purchasing power

\section{Market Area Considerations}

Consideration of the intended market area is:

a. Population dimension

b. Public transportation and road network

c. Economic characteristics and purchasing power are effective

d. Market potential in terms of goods

e. Consumer tastes

f. Intensity of competition

g. Distribution ability

h. Environmental characteristics

i. Restrictions on regulations and zoning

j. Business climate

3. Site Characteristics Considerations

Consideration of the characteristics is

a. Tread Profile (size and shape)

b. Need for rent/land price

c. Parker Ratio

d. Pedestrian Flow

e. Public Transport Access

f. Visibility

g. Access to the trading area

f. Population conditions

Some determinants of the development of trading locations are:

a. A number of supporting population is the number of potential customers as a customer in a sales transaction.

b. Accessibility, related to the ease of achievement of a location through public and private vehicles and pedestrian. For the facility of easy easiness of location, traffic smoothness and existence of parking area become one of the conditions of determination of location and success of sale business activity.

c. Distance, the tendency of buyers to shop at a location not too far away from where he lives.

\section{d. Completed trading facilities}

This research uses several criteria which are the most important to provide the model that can be used in determining the most appropriate location to market their products. The results from the implementation model is a sequence of recommendations can be used by the community to choose a marketing location that best suits the situation and conditions.

\section{METHOD}

In this research, the method used is analytical hierarchy process which is implemented to help make decisions in choosing the most suitable marketing location based on several assessment criteria and the alternatives provided. The framework method of this research can be seen in Fig. 1 below.

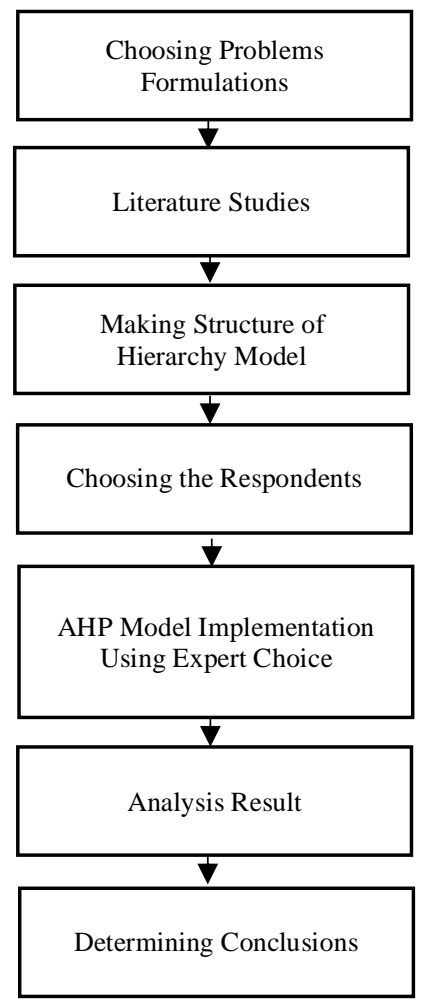

Fig. 1. Research Framework

The problem formulation of this research was obtained from the initial research that found that to determine the location of product marketing must be based on criteria. The criteria used in this research were obtained based on a review of some literature, both from the management, business and marketing sciences, as well as literature related to recommendation methods using AHP.

In the stage of creating a hierarchical model structure, not all criteria obtained from the literature review are used as criteria that are used in the hierarchical model but adjusted to the level of criteria that are most suitable to be implemented into three alternative marketing locations, namely locations close to the entertainment location area, close to the tourist area, and close to educational area. 
After a hierarchical structure model is obtained, the next step determines the prospective respondents who will conduct the assessment. Respondents in this research determined that the sellers from the most creative types of industries are sellers of fashion products, sellers of culinary products and seller of handicraft products.

The results of the assessment of the three sellers are then combined and the process of analyzing the results of data processing using Expert Choice tools so that the results of the analysis are obtained in the form of a recommendation rating from the most suitable marketing location.

\section{RESULT}

\section{A. Structure of Research Hierarchy Model}

The goal determined in the hierarchical structure is to determine the location of creative industry marketing. There are four criteria used in the hierarchical model, namely accessibility, supporting facility, competitor, and target market. The hierarchical structure model in this research can be seen more fully in Fig. 2.

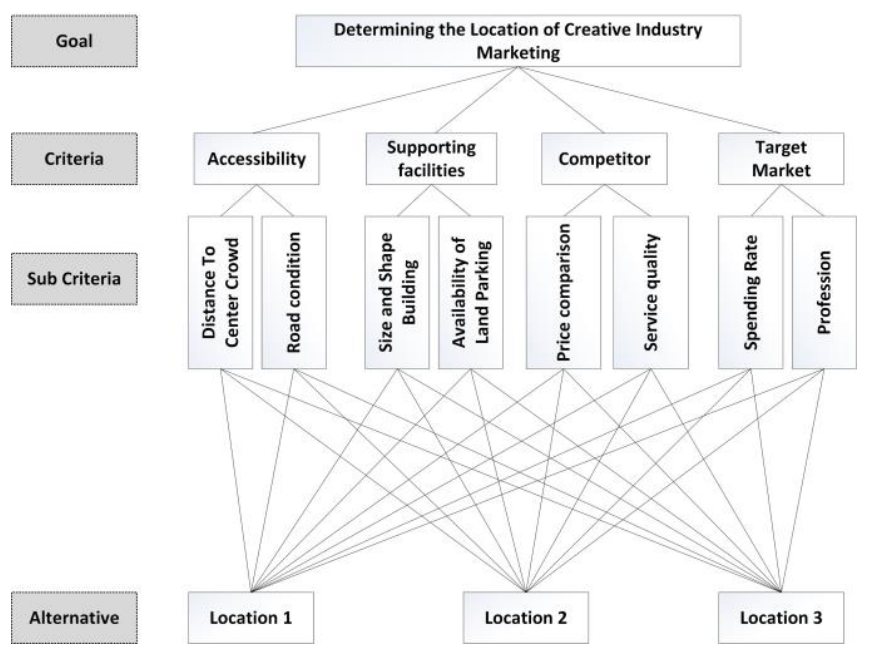

Fig. 2. Model Hierarchy

To test the model made in this research, the determination of the location of the alternative by the researchers based on creative phenomena. The determination of the future location can be determined and can be changed by the business actors themselves but still using the model built at this time. These three locations area can be seen in table 1 .

TABLE I. LOCATION AREA DESCRIPTION

\begin{tabular}{|l|l|}
\hline \multicolumn{1}{|c|}{ Alternative } & \multicolumn{1}{c|}{ Place Description } \\
\hline Location 1 & Near the entertainment area \\
\hline Location 2 & Near the tourist area \\
\hline Location 3 & Near the educational area \\
\hline
\end{tabular}

Respondents involved in the site selection assessment consisted of 3 respondents from each of the different creative industry business seller. Detail respondents can be seen in table 2 .
TABLE II. RESPONDENTS DESCRIPTION

\begin{tabular}{|l|l|}
\hline No. Respondents & \multicolumn{1}{|c|}{ Type Creative Industry } \\
\hline 1st respondent & A seller of fashion product \\
\hline 2nd respondent & A seller of culinary product \\
\hline 3rd respondent & A seller of handicraft product \\
\hline
\end{tabular}

Tools Expert Choice is used to perform calculations and analysis process of inputs assessment of the three respondents against the criteria that exist in the hierarchy model. In the process of calculation and analysis using expert choice, it is necessary to check the consistency of the hierarchy (Consistency Ratio). If the value of CR is greater than 0.1 then the hierarchical judgment made is said to be invalid and must be corrected or repeated. Whereas if the value of CR obtained is smaller or equal to than 0.1 then the result of the hierarchy assessment made is said to be true or consistent.

\section{B. Calculation and Analysis Results}

The results of the calculations carried out the explanation is divided into three perspectives, in accordance with the assessment of three respondents.

B.1. The results of the calculation based on the views of the seller fashion product.

The results of the assessment of the views of a fashion product seller can be seen in Fig 3.

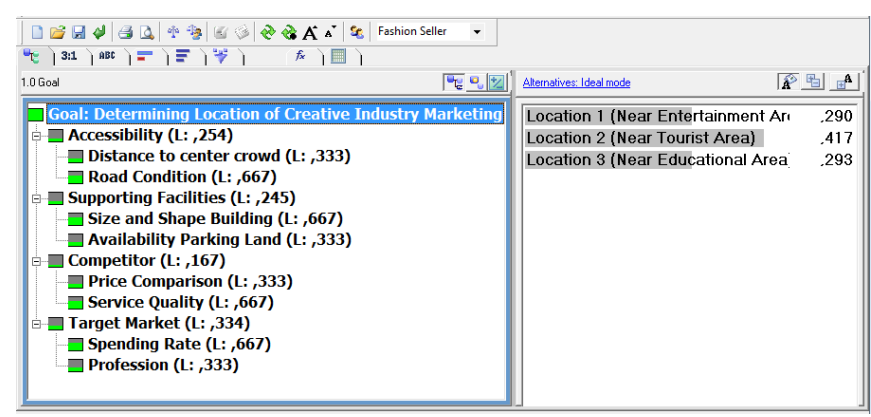

Fig. 3. The results of the calculation of the outlook fashion seller

Based on the results shown in fig 3 obtained results that are based on the view of a seller fashion product target market criteria have the highest level of importance compared to the other three criteria. Target market criteria get value 0.334 followed by accessibility criteria with value 0,254 , a criterion of supporting facilities get value 0,245 and criteria of the competitor to get last order with value 0,167 . The assessment means that in determining the location of marketing of fashion products, the factor that must take precedence is that the marketed product must be in accordance with the target market in a location.

Fig. 3 also displays the recommended location outcomes where suggested product marketing, with the highest ranking for selling fashion products, turned out to be in an adjacent location or in the vicinity of tourist attractions with a score of 0.417. This appraisement is valid because it obtains $\mathrm{CR}=$ 0.08 as shown in Fig. 4. 


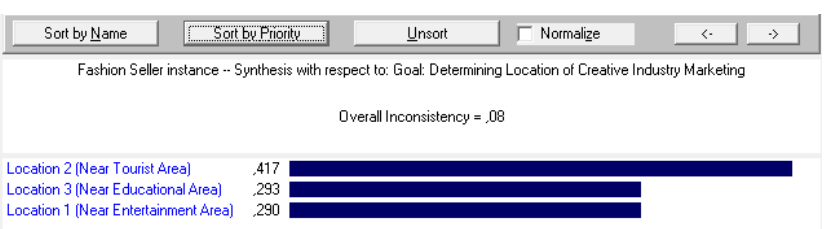

Fig. 4. CR value seller fashion product

B.2. The calculation results are based on the views of the culinary product seller.

The recommendation of the result of the culinary product seller is different from the recommendation from the seller of a fashion product. For the most influential criteria in determining the location of marketing of culinary products, namely supporting facilities with a value of 0.493 . Target market criteria which if in seller fashion is ranked first, currently, it ranks third with a value of 0.149 after accessibility ratings are ranked second with a value of 0.239 . The full results can be seen in Fig. 5.

\begin{tabular}{|c|c|}
\hline 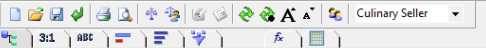 & \\
\hline $1.0 \mathrm{G}$ Gal & Alerenatives: Ideal mode \\
\hline 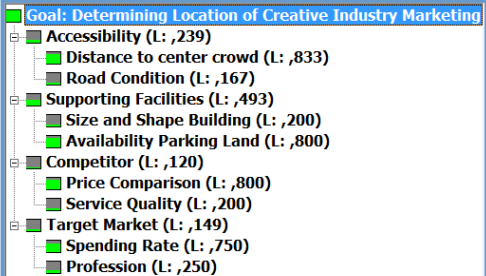 & \begin{tabular}{|ll} 
Location 1 (Near Entertainment Are & .438 \\
Location 2 (Near Tourist Area) & .197 \\
Location 3 (Near Educational Area) & .364
\end{tabular} \\
\hline
\end{tabular}

Fig. 5. A result of the calculation of the culinary seller product assessment

Alternative locations of culinary product marketing also have different recommendation ratings with the marketing location of fashion products. Based on the result of the calculation shown in figure 5 it is found that location 1 near entertainment area has the highest recommendation value that is 0.438 followed by location 2 near an educational area with value 0,364 . Thus, the location of marketing near tourist attraction is not recommended as a marketing location culinary product.

CR value obtained from the culinary seller product assessment is also valid by obtaining a consistency ratio of 0.08 as shown in Fig. 6 .

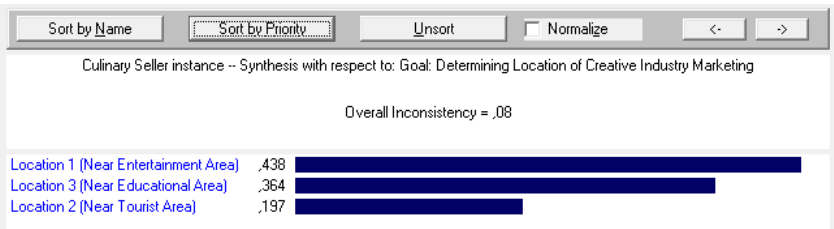

Fig. 6. CR value of culinary seller product

B.3. The calculation results are based on the assessment of the handicraft seller product.

Assessment of recommendations by handicraft seller product results can be seen in Fig. 7 below.

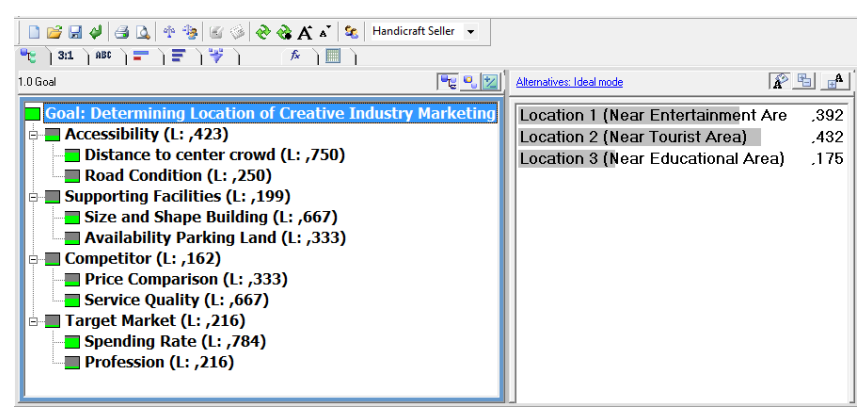

Fig. 7. The result of calculation of assessment by handicraft seller product

Different from the results of the two previous assessments, for the results of calculations by handicraft product seller obtained that accessibility criteria have the highest influence when compared with the other three criteria, while the recommended location as a place for handicraft product marketing is the location adjacent to the tourist attractions. Accessibility criteria got a value of 0.423 , while the alternative location 2 near tourist area received a recommendation value of 0.432 . Consistency Ratio value obtained that is equal to 0.08 so that all assessments made are declared valid. The CR value can be seen in Fig. 8 .

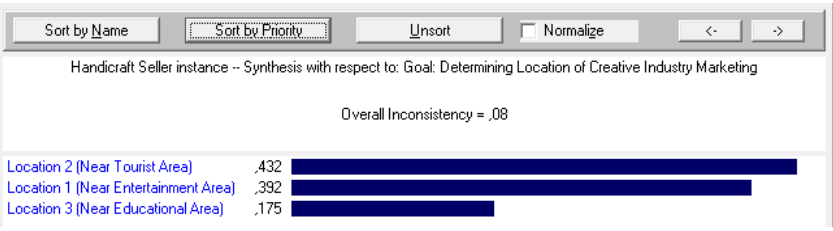

Fig. 8. CR value of handicraft seller product

The results of the assessment have been done is not binding because the assessment items are done is very dependent on the characteristics and individuals of each assessor. If the reassessment is done with different respondents, it is certain that the result of the location recommendation assessment will also get the different value.

This assessment is also done fairly by one respondent for each type of creative industry. This is because AHP does not require a large number of respondents. All items assessed in this research is valid because have a consistency ratio of 0 0,1 [24-26].

\section{DiscUSSION}

This research has been able to provide a recommendation of the location marketing area of creative industry products that best suits the situation and condition. The model used is valid even if the assessment is done by three different sources. The results of the recommended values will vary depending on the intuition of the assessors. This model is also implemented and tested only to 3 different seller stakeholders, namely fashion seller, culinary seller, handicraft seller. So that the recommendations given will be more suitable when compared to respondents who are only one person [27]. It is certain that the results will differ if those who do the assessment outside the 3 types of creative industries business.

\section{CONCLUSION}

The model built in this research can be used to determine the location of the appropriate marketing area in accordance 
with the type of creative industries marketed, but in the assessment process is still dependent on the individual each respondent so that if there are respondents who are less clear in understanding each question posed, then the process of calculating the value of the recommendation will also be biased. The criteria and subcriteria used in this assessment can also be used as a decision support model to determine the exact marketing location of the creative industry.

\section{ACKNOWLEDGMENT}

Authors wishing acknowledge to KEMENRISTEKDIKTI for help and support this research using grant Penelitian Strategis Nasional Institusi (PSN Institusi) 2018.

\section{REFERENCES}

[1] Purwaningsih, R. and Kusuma, P.D. "Analisis Faktor-faktor yang mempengaruhi Kinerja Usaha Kecil dan Menengah (UKM) dengan metode Structural Equation Modeling (Studi Kasus UKM Berbasis Industri Kreatif Kota Semarang)". Prosiding SNST Fakultas Teknik, 1(1). 2015.

[2] Lestiani, M.E. "Faktor-Faktor Dominan Promosi Yang Mempengaruhi Motivasi Konsumen Dalam Membeli Suatu Produk Dengan Menggunakan Metode Ahp". Jurnal Industri Elektro dan Penerbangan, 1(1). 2018.

[3] Ramadhani, Y. "Pengaruh Lokasi dan Promosi Terhadap Niat Beli Konsumen (Studi Kasus Pada Hypermart Giant Jababeka Cikarang)". Jurnal Pelita Ilmu, 8(2). 2018.

[4] Febriana, E.K., Yulianeu, Y., Harini, C. and Warso. "Pengaruh Keragaman Produk, Kualitas Produk dan Lokasi Penjualan Terhadap Kepuasan Konsumen”. Journal of Management, 3(3). 2017.

[5] R. Wahdiniwaty, E. B. Setiawan and D.A. Wahab, "Creative Industry Potential Model for Micro, Small and Medium Scale in West Bandung Based on Geographic Information System," International Business Management, vol. 11, no. 4, pp. 841-849, 2017.

[6] E. B. Setiawan. "Sistem Informasi Geografis Untuk Pemetaan Potensi Usaha Industri Kreatif”. Jurnal CoreIT, vol. 2. no.1. pp.1-7, 2016.

[7] D. A. Wahab, E.B. Setiawan, R. Wahdiniwaty. "Information of Tourism and Creative Industry Using Mobile Application Technology". International Journal of New Media Technology (IJNMT). pp. 120-125. 2017.

[8] Macchion, L., Moretto, A.M., Caniato, F., Caridi, M., Danese, P. and Vinelli, A., 2017. International e-commerce for fashion products: what is the relationship with performance? "International Journal of Retail \& Distribution Management, 45(9), pp.1011-1031. 2017

[9] Lee, A.H., Wall, G., Kovacs, J. and Kang, S.Y. "Food clusters and creative tourism development: A conceptual framework". Journal of Rural and Community Development, 11(2). 2017.

[10] Aripin, N., Arifin, R. and Slamet, A.R. "Pengaruh Faktor Lokasi, Kelengkapan Produk dan Harga Terhadap Pembelian Ulang Konsumen”. Jurnal Ilmiah Riset Manajemen, 6(06). 2017.

[11] Krisdayanto, I., Haryono, A.T. and Gagah, E. "Analisis Pengaruh harga, Kualitas Pelayanan, Fasilitas dan Lokasi Terhadap Kepuasan Konsumen". Journal of Management, 4(4). 2018.

[12] Andalia, F. "Implementation Analytical Hierarchy Process On Airplane Ticket Booking Application Selection With Software Quality Requirements and Evaluation ISO/IEC 25010: 2011". International Journal of New Media Technology, 4(2), pp.126-130. 2017.

[13] Koç, E. and Burhan, H. A. 'An Application of Analytic Hierarchy Process (AHP) in a Real World Problem of Store Location Selection', Advances in Management \& Applied Economics, 5(1), pp. 41-50. 2015 .

[14] Singh, T., Patnaik, A., Chauhan, R. and Chauhan, P. "Selection of brake friction materials using hybrid analytical hierarchy process and vise Kriterijumska Optimizacija Kompromisno Resenje approach". Polymer Composites, 39(5), pp.1655-1662. 2018.

[15] Jain, V., Sangaiah, A.K., Sakhuja, S., Thoduka, N. and Aggarwal, R. "Supplier selection using fuzzy AHP and TOPSIS: a case study in the Indian automotive industry". Neural Computing and Applications, 29(7), pp.555-564. 2018.

[16] Andri Suryadi, Dian Nurdiana. "Sistem Pengambilan Keputusan Untuk Pemilihan Teknisi Lab Dengan Multikriteria Menggunakan Metode AHP". Jurnal Pendidikan Matematika, April, 5(1), pp. 11-21. 2015

[17] Sestri, E. "Penilaian Kinerja Dosen Dengan Menggunakan Metode AHP Studi Kasus di STIE Ahmad Dahlan Jakarta”. Jurnal Liquidity, 2(1), pp. 100-109. 2013.

[18] Rusdiana, "Manajemen Operasi," Bandung: CV. Pustaka Setia,2014.

[19] Taleizadeh, A.A. and Noori-daryan, M. "Pricing, manufacturing and inventory policies for raw material in a three-level supply chain". International Journal of Systems Science, 47(4), pp.919-931, 2016.

[20] Suliyanto, "Studi Kelayakan Bisnis Pendekatan Praktis," Yogyakarta: C.V Andi Offset,2010.

[21] Chen, L.F. and Tsai, C.T. "Data mining framework based on rough set theory to improve location selection decisions: A case study of a restaurant chain". Tourism Management, 53, pp.197-206, 2015.

[22] Huang, X. "The impact of strategic market entry considerations on the financial performance of Chinese investment in the Australian mining industry". Thunderbird international business review, 57(4), pp.323339, 2015.

[23 Barbour, V., Burch, D., Godlee, F., et al,. "Characterisation of trials where marketing purposes have been influential in study design: a descriptive study". Trials, 17(1), p.31, 2016.

[24] Mastura, M., Sapuan, S. and Mansor, M. "A framework for prioritizing customer requirements in product design: Incorporation of FAHP with AHP”. Journal of Mechanical Engineering and Sciences, vol. 9, pp.1655-1670, 2015.

[25] Capraz, O., Meran, C., Wörner, W. and Gungor, A. "Using AHP and TOPSIS to evaluate welding processes for manufacturing plain carbon stainless steel storage tank". Archives of Materials Science, 158, p.158, 2015.

[26] Abdel-Basset, M., Mohamed, M., Zhou, Y. and Hezam, I., "Multicriteria group decision making based on neutrosophic analytic hierarchy process". Journal of Intelligent \& Fuzzy Systems, 33(6), pp.4055-4066, 2017.

[27] Irawan, R. and Winiarti. "Sistem Pendukung Keputusan Pemilihan Lokasi dan Evaluasi Lokasi Pemasaran Produk (Gula) Menggunakan Metode AHP (Studi Kasus: PT. Madubaru)". Jurnal Informatika, 9(2), pp.1079-1087, 2015. 